\title{
JAJAN CENIL (JAGA JANIN DENGAN CEGAH ANEMIA IBU HAMIL) PADA MASA PANDEMI COVID-19 DI KELURAHAN PASIR PUTIH DEPOK
}

\author{
Sintha F Simanungkalit ${ }^{1}$, Ikha Deviyanti Puspita ${ }^{2}$, A'immatul Fauziah ${ }^{3}$ \\ ${ }^{1,2,3}$ Program Studi Ilmu Gizi Universitas Pembangunan Nasional Veteran Jakarta \\ Kampus II FIKES UPN Veteran Jakarta Jl. Limo Raya, Depok, Jawa Barat 16515 \\ ${ }^{1}$ Surel: sintha_fs@yahoo.com
}

\begin{abstract}
Yuviska's research activities found that anemia can be influenced by nutritional status, knowledge, and compliance with Fe tablet consumption (Yuviska, 2017). The World Health Organization (2011) states that anemia is a condition where the number of red blood cells is insufficient to meet the physiological needs of the body. The purpose of the abdimas activity in Pasir Putih Village is to increase the knowledge of cadres and pregnant women in preventing anemia in pregnant women during the Covid-19 pandemic. The location of this community service was carried out in Pasir Putih Village, Sawangan Depok. This community service activity is in the form of providing nutrition education with online counseling methods with cadres and pregnant women attending. Counseling is held on weekends using zoom and weekdays via What's App. This activity takes place online because there are still many areas that are still Covid-19 red zones. Based on the analysis of the results of the pre-test and post-test answers, it was found that there was a difference in knowledge before and after counseling for cadres and pregnant women with $p<0.005$. Community service activities in the form of counseling are quite effective in changing the knowledge of cadres and pregnant women.
\end{abstract}

Keywords: anemia, online, education, knowledge

\begin{abstract}
ABSTRAK
Kegiatan penelitian Yuviska mendapatkan bahwa anemia dapat dipengaruhi oleh status gizi, pengetahuan, dan kepatuhan konsumsi tablet Fe (Yuviska, 2017). World Health Organization (2011) menyebutkan anemia yaitu adalah sesuatu kondisi dimana jumlah sel darah merah tidak mencukupi dalam memenuhi dari kebutuhan fisiologis tubuh. Tujuan kegiatan abdimas di Kelurahan Pasir Putih adalah meningkatkan pengetahuan para kader dan ibu hamil dalam pencegahan anemia pada ibu hamil pada masa pandemic Covid-19. Lokasi pengabdian masyarakat ini dilaksanakan di Kelurahan Pasir Putih, Sawangan Depok. Kegiatan abdimas ini berupa pemberian edukasi gizi dengan metode penyuluhan daring dengan peserta yang hadir kader dan ibu hamil. Penyuluhan diadakan di akhir pekan dengan menggunakan zoom dan hari kerja via What's App. Kegiatan ini berlangsung secara daring dengan daring dikarenakan masih banyak daerah yang masih zona merah Covid-19. Berdasarkan analisis hasil jawaban pre test dan post test didapatkan ada perbedaan pengetahuan sebelum dan sesudah penyuluhan pada para kader dan ibu hamil dengan nilai $\mathrm{p}<0,005$. Kegiatan pengabdian masyarakat berupa penyuluhan cukup efektif merubah pengetahuan para kader dan ibu hamil.
\end{abstract}

Kata kunci: anemia, daring, edukasi, pengetahuan

\section{PENDAHULUAN}

Ibu yang sedang hamil sangat peka terhadap infeksi dan penyakit menular. Peradangan baik kronis danakut, kelainan bawaan dan infeksi parasit yang dapat mempengaruhi pembentukan dari $\mathrm{Hb}$, ketidakcukupan produksi dari sel darah merah ini akan bisa menyebabkan anemia(5). Berdasarkan data Riskesdas tahun 2018, angka kejadian anemia ibu hamil di Indonesia meningkat yaitu dari 37,1\% tahun 2013 menjadi 48,9\% tahun 2018 ibu hamil yang mengalami anemia(1). Sedangkan pada tahun 2010 prevalensi anemia pada ibu hamil di kota Depok sebanyak $35,1 \%$. Rendahnya cakupan pemberian TTD dapat menjadi penyebab meningkatnya angka anemia pada ibu hamil. Gejala-gejala yang umumnya adalah lemah, mengantuk, pusing, lelah, malaise, sakit kepala, anoreksia, mual dan muntah, konsentrasi hilang. Temuan pada 
pemeriksaan dapat meliputi kulit pucat, mukosa, gusi, kuku jari pucat. Anemia dapat berdampak buruk bagi ibu dan anak, ibu dapat mengalami depresi, pendarahan bahkan kematian, dan bayi dapat mengalami berat bayi lahir rendah, premature, anemia pada bayi bahkan kematian janin(8). Faktor yang mempengaruhi anemia ibu hamil dapat dibagi menjadi faktor dasar yaitu social ekonomi, pengetahuan dan pendidikan, faktor tidak langsung yaitu kunjungan Antenatal

Care (ANC) dan umur ibu, dan faktor langsung yaitu asupan gizi besi, kecukupan konsumsi tablet besi, jarak kehamilan, status gizi, dan penyakit infeksi(2). Kegiatan pengabdian masyarakat ini bertujuan memberikan edukasi gizi dalam pencegahan anemia pada ibu hamil dan para kader di masa pandemic Covid-19.

\section{METODE PELAKSANAAN PKM}

Pemilihan lokasi pengabdian kepada masyarakat ini berdasarkan permasalahan yang ada bahwa sesuai data dari tahun ke tahun banyak ibu hamil mengalami anemia khusunya masa pandemi. Hal ini dikarenakan terbatasnya akses para ibu hamil ke posyandu dan tidak diadakannya lagi penyuluhan secara langsung kepada ibu hamil dan kader mengingat beberapa wilayah RW Kelurahan Pasir Putih merupakan zona merah Covid-19. Adapun jumlah peserta kegiatan ini sebanyak 30 orang terdiri atas kader dan ibu hamil.

Kegiatan pengabdian masyarakat ini berlangsung dalam penyuluhan online dengan memakai aplikasi zoom. Tim pengabdi masyarakat sebelumnya telah berkoordinasi dengan pihak kelurahan, pihak Puskesmas dan para kader. Kegiatan pengabdian masyarakat ini juga dibantu oleh para mahasiswa dan berlangsung jam 10.00WIB. Adapun urutan kegiatan sebagai berikut:

1. 10.00-10.25 WIB : Pembukaan

2. 10.25-10.30 WIB : Pretest

3. 10.30-10.50 WIB : Pemberian materi berupa Softfile Leaflet dan Video tentang Anemia

4. 10.50-11.00 WIB : Diskusi dan tanya jawab

5. 11.05-11.10 WIB : Posttest

6. 11.15-11.30 WIB : Pengumuman nilai tertinggi untuk post test dan penyerahan hadiah

Kuesioner pre test dan post test yang telah diisi oleh peserta akan dinilai oleh tim. Setelah didapatkan skor pre test dan post test maka tim akan menganalisis untuk melihat apakah ada perubahan pengetahuan kader dan ibu hamil sebelum dan sesudah diberikan penyuluhan.

\section{HASIL DAN PEMBAHASAN}

Kegiatan pengabdian masyarakat diselenggarakan dalam bentuk penyuluhan via daring menggunakan zoom mengenai pencegahan anemia ibu hamil saat pandemic Covid-19. Berikut gambar kegiatan: 


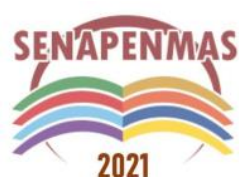

2021
Seminar Nasional Hasil Penelitian dan Pengabdian Kepada Masyarakat 2021

Pengembangan Ekonomi Bangsa Melalui Inovasi Digital Hasil Penelitian dan Pengabdian Kepada Masyarakat Jakarta, 21 Oktober 2021

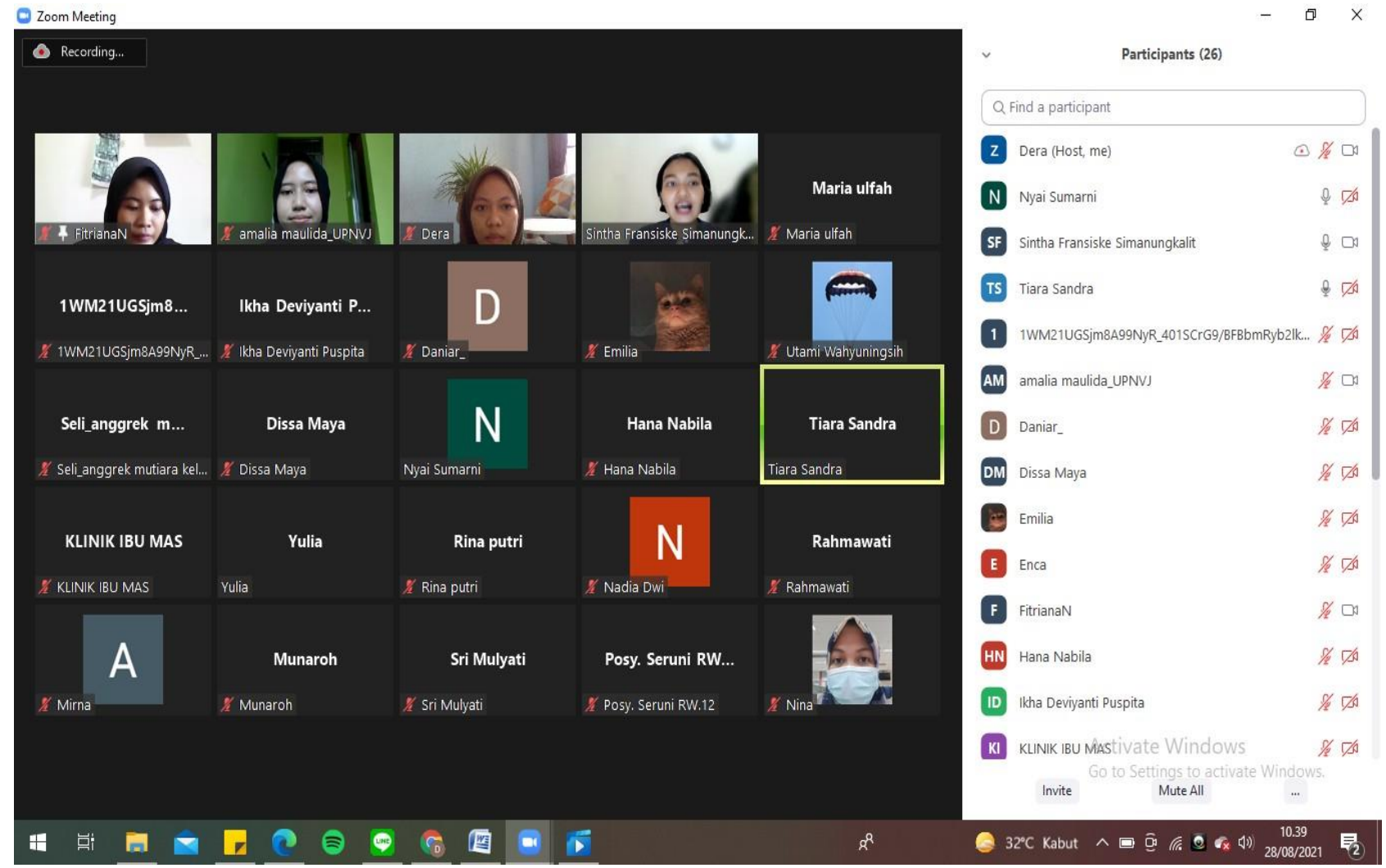

\section{Gambar 1. Kegiatan Penyuluhan via zoom}

\section{KuisionerAnemialbuHamil-Goo $\times$ I PretestAnemialbuHamil (Jawabai $x$}

t PostestAnemialbuHar C $\mathrm{C}$

docs.google.com/spreadsheets/d/19r-aD9StJGc0Qv1B2LoSccC4F9TE8awu2 粠 Apps

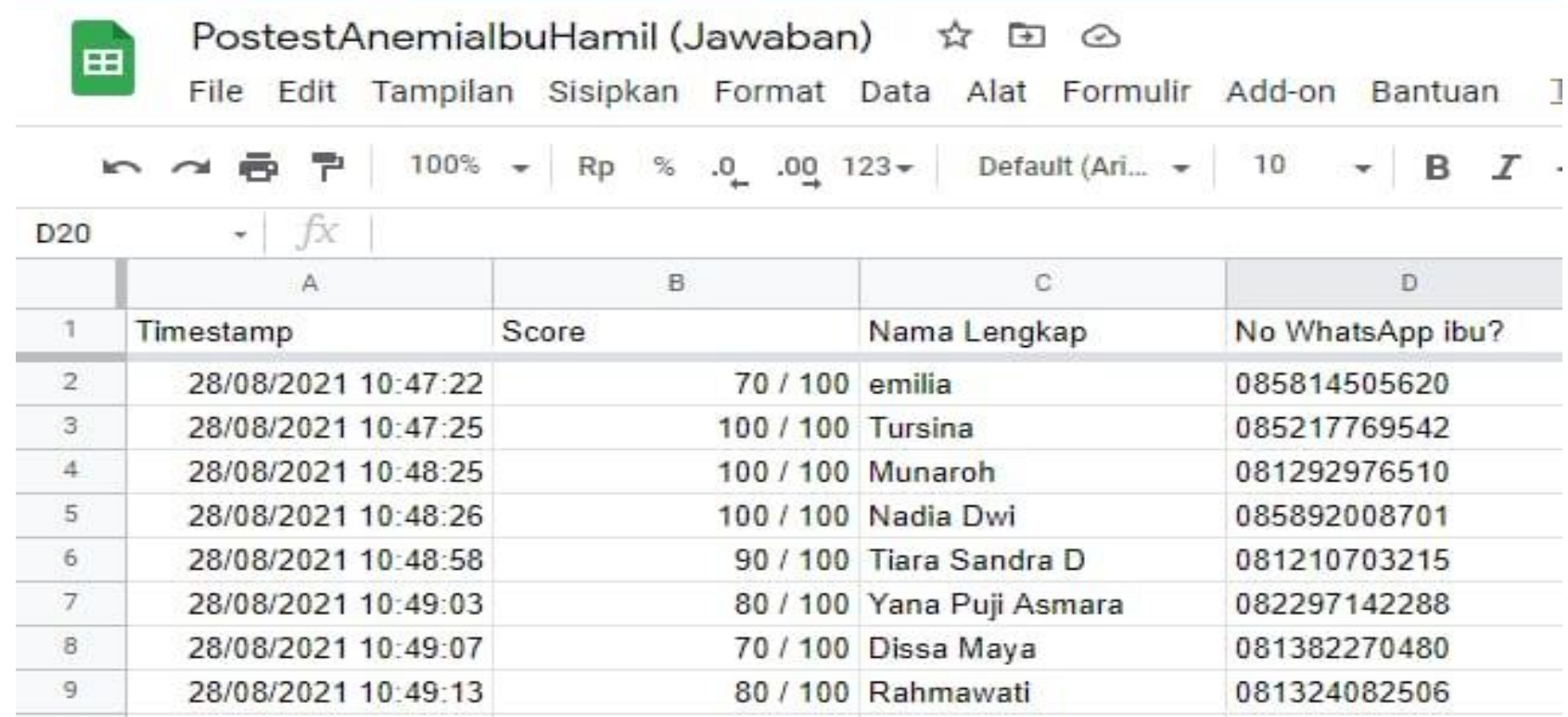

Gambar 2. Rekapan Hasil Pre Test dan Post Test via gform 
Tim pengabdian masyarakat juga tidak lupa menyimpan file di dalam google drive. Berikut hasil analisis statistic kegiatan penyuluhan:

Tabel 1. Nilai Pre Test

\begin{tabular}{lcc}
\hline Kategori Pengetahuan & Jumlah Peserta (Kader dan Ibu Hamil) & Persentase (\%) \\
\hline Kurang (Skor $<60)$ & 21 & 70 \\
\hline Baik (Skor $>=60)$ & 9 & 30 \\
\hline
\end{tabular}

Berdasarkan tabel diatas, pada saat pre-test ditemukan sebagian besar responden (ibu) memiliki kategori pengetahuan yang kurang sebanyak 21 orang (70\%) dengan rentang skor untuk kategori pengetahuan kurang yaitu dibawah 60 .

Tabel 2. Nilai Post Test

\begin{tabular}{lcc}
\hline Kategori Pengetahuan & Jumlah Peserta (Kader dan Ibu Hamil) & Persentase (\%) \\
\hline Kurang (Skor $<60)$ & 0 & 0 \\
\hline Baik (Skor $>=60)$ & 30 & 100 \\
\hline
\end{tabular}

Setelah mendapatkan edukasi menggunakan media video dan leaflet, terlihat dari hasil skor posttest sebagian besar responden pengetahuannya cenderung meningkat menjadi sebanyak 30 orang $(100 \%)$ memiliki pengetahuan baik.

Tabel 3 Uji Perbedaan

\begin{tabular}{lcc}
\hline \multicolumn{1}{c}{ Nilai Responden } & Mean Rank & p-value \\
\cline { 1 - 2 } Pre Test & 16,27 & 0,00 \\
\hline Post Test & 44,73 & \\
\hline
\end{tabular}

Berdasarkan hasil analisis didapatkan nilai sig. sebesar $0,000(<0,05)$ yang berarti Ho ditolak maka terdapat perbedaan skor antara pretest dan posttest pada kuisioner. Maka dapat diambil kesimpulan bahwa kegiatan pengabdian masyarakat efektif dalam merubah dan menambah pengetahuan para kader dan ibu hamil. Hasil yang sama dengan kegiatan masyarakat di Haurpanggung bahwa ada erubahan pengetahuan bagi kader dan ibu hamil tentang anemia. Kader sebagai ujung tombak penggerak kesehatan di masyarakat untuk meningkatkan dukungan sosial pada ibu hamil dengan anemia (Sukowati, 2018). Penelitian Otaviani dan Maria tahun 2019 juga mendapatkan bahwa ada peningkatan pengetahuan ibu hamil dan anemia (Oktaviani, 2019). Hasil post test menunjukkan adanya peningkatan rata-rata pengetahuan antara pre test dan post test kader di Cilacap juga didapatkan Frisca dkk dalam kegiatan pengabdian masyrakat (Frisca, dkk., 2020). Peningkatan pengetahuan tersebut terjadi akibat dari komunikasi efektif yang terjalin antara penyuluh dan responden (Safitri, 2020). Pendidikan kesehatan dapat mengubah pengetahuan, sikap dan perilaku tentang pencegahan anemia selama kehamilan. Salah satu bentuk kegiatan pendidikan kesehatan menggunakan metode penyuluhan akan menambah pengetahuan pada ibu hamil, dimana hal ini akan membentuk sikap positif para ibu hamil terhadap materi tentang anemia yang baru mereka pelajari itu. Akhirnya timbulah rangsangan yakni materi tentang anemia yang berupa tindakan terhadap atau sehubungan dengan stimulus atau materi tentang anemia (Kiftiyah, 2015).

\section{KESIMPULAN DAN SARAN}

Kegiatan pengabdian masyarakat yang dilakukan dengan metode daring ini terbukti efektif dalam meningkatkan pengetahuan para kader dan ibu hamil sehingga diharapkan para ibu hamil dapat mencegah dirinya mengalami anemia selama masa pandemic Covid-19. Tim pengabdian 


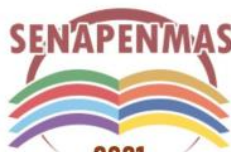

2021
Seminar Nasional Hasil Penelitian dan Pengabdian Kepada Masyarakat 2021

Pengembangan Ekonomi Bangsa Melalui Inovasi Digital Hasil Penelitian dan Pengabdian Kepada Masyarakat Jakarta, 21 Oktober 2021

masyrakat menyrankan para kader dapat memberikan edukasi gizi anemia pada ibu hamil di lingkungan tempat tinggalnya. Para ibu hamil yang berpartisipasi dalam kegiatan ini diharapkan dapat memberikan edukasi kepada keluarga atau tetangga yang sedang hamil sehingga dapat mencegah anemia selama masa pandemic Covid-19.

\section{Ucapan Terima Kasih}

Tim pengabdian masyarakat berterima kasih kepada LPPM UPN Veteran Jakarta atas bantuan dana yang diberikan. Tim pengabdian juga berterima kasih kepada FIKES UPN Veteran Jakarta, Kelurahan Pasir PUtih, Puskesmas Pasir Putih dan segenap para kader yang memberikan fasilitas dan izin kepada tim pengabdian masyarakat sehingga kegiatan ini dapat berjalan dengan baik.

\section{REFERENSI}

Yuviska IA. Faktor-Faktor Yang Berhubungan Dengan Kejadian Anemia Pada Ibu Hamil Trimester Iii Di Bps Desi Andriani Kelurahan Sukaraja Bandar Lampung Tahun 2016. Jurnal Kesehatan Holistik ( The Journal Of Holistic Healthcare ), Volume 11, No . 3 , Juli 2017 : 132-139. 2017;11(3):132-9.

Frisca Dewi Y.,dkk., (2020). Pemberdayaan Kader Dalam Upaya Pencegahan Dan Penanggulangan Anemia Ibu Hamil. Jurnal Pengabdian Masyarakat Al Irsyad (JPMA) Vol. 2 No. 2 (2020): Vol. II, No. 2, Oktober 2020. $\underline{\text { http://e- }}$ jurnal.stikesalirsyadclp.ac.id/index.php/jpma/article/view/144

Kementrian Kesehatan RI. (2018). Riset Kesehatan Dasar 2018. Badan Penelitian dan Pengembangan Kesehatan Kementrian Kesehatan RI.

Kiftiyah. Pengaruh Penyuluhan Kesehatan pada Ibu Hamil tentang Anemia terhadap Perilaku Pencegahan Anemia Selama Kehamilan. JKK. 2015;1(2):87-93.

Safitri. (2020). Pendidikan Kesehatan tentang Anemia kepada Ibu Hamil. Jurnal Abdimas Kesehatan. Vol 2, No 2 (2020) http://jak.stikba.ac.id/index.php/jak/article/view/88

Sukmawati, dkk. (2018). Pemberdayaan Masyarakat Dalam Upaya Pencegahan Dan Penanganan Anemia Pada Ibu Hamil Di Puskesmas Haurpanggung. Jurnal Pengabdian Kepada Masyarakat. Vol 2, No 9 (2018).

http://jurnal.unpad.ac.id/pkm/article/view/20114

Oktaviani \& Maria J.R. (2019). Peningkatan Pengetahuan dan Sikap Ibu Hamil tentang Anemia pada Kehamilan dengan Media Video dan Lembar Balik. Jurnal Kesehatan Metro Sai Wawai. Vol 12, No 1 (2019). http://www.ejurnal.poltekkestjk.ac.id/index.php/JKM/article/view/1784 
Seminar Nasional Hasil Penelitian dan Pengabdian Kepada Masyarakat 2021

Pengembangan Ekonomi Bangsa Melalui Inovasi Digital Hasil Penelitian dan

Pengabdian Kepada Masyarakat

Jakarta, 21 Oktober 2021

(halaman kosong) 